\title{
巻縮紡績系の集合構造に関する研究
}

（第 2 報） 巻縮繊維間の位相ずれとその計測

$\begin{array}{llllll}\text { (株) クラレ 山 } & \text { 口 } & \text { 新 } & \text { 司 (会員) } \\ \text { 京 都 大 } & \text { 学 } & \text { 川 } & \text { 端 } & \text { 季 } & \text { 雄 (会員) }\end{array}$

\section{Analysis of Yarn Structure of Crimped Fiber Assemblies.}

\section{Part 2: Measurement of Phase Difference between Crimp Waves.}

\author{
Sinji Yamaguchi* and Sueo Kawabata** \\ * Fiber Research Laboratories, Kuraray Co., Ltd., Kurashiki, Okayama-ken. \\ ** Department of Polymer Chemistry, Kyoto Unversity, Kyoto.
}

\begin{abstract}
In the previous paper, the structure of assembled helical coils has presented as a model of crimped yarns. And from the theoretical anlysis of this structure, the distribution of the phase angle between fibers takes different distribution with an average size of crimp frequency of fibers.

This article describes a method how to measure the phase angle of fibers in yarn, and examines some crimped yarn what distribution of the yarn takes. Phase difference can be calculated by mutual correlation function $R(\tau)$ between two waves of crimp. That is, the value of the correlation function takes maximum value when the two phase angles are coincident. The experimental results are agreed with the phase distribution which can be estimated assumed from the theoretical anlysis.
\end{abstract}

(Received November 12, 1971)

摘要

目 的 繊維の巻縮を一つの波形飞おきかえるとき，繊維相互間の巻縮波の位相差は系の集合構造を決める重要な 要素であるが, この位相差の計测方法を提出し, 実際の系がどのような位相差をすつかを調查し, 巻縮性と位相差の 関係について実験的に明らかにする。

成 果（1）系内の巻縮波の位相ずれは各瀻維の巻縮波形間の相互相関関数で把握することができた。 （2）巻縮数の少ない繊維の系は波形が比較的よくそろって相互相関係数は高い值を示すが，巻縮数の多いものは波 形がランダムになっているととが観察され，相互相関関数の最大值が小さい值を示し，巻縮ピッチが一定であるとす るモデル構造からのずれが認められた。

（3） 2 本の繊維間の巻縮の位相のずれは巻縮波形の相互相関関数が最大の值を示すときの角度より計算でき，系 のバルキー性から逆算して推定される位相差の分布とほほ一致した。この結果は第 1 報の系の集合構造理論の妥当性 を示すあのである。

（昭和 46 年 11 月 12 日受理） 


\section{1. 緒言}

糸の集合構造を単繊維の巻縮特性から理論的に導くた め第 1 報ではへリカル コイルの集合構造の理論を提案 した。すなわちクリンプをあつ緎維の集合体として，同 じ周期, 半径を有するへリカル コイルの群がコイル軸 を平行にして，位相のずれをあちながら接触しあうま で接近するモデルで糸を表現した。

任意の二つの繊維すなわち二つのヘリカルコイル内 の位相のずれ $\theta$ が $0 \sim 2 \pi$ の間を一様に分布する場合， および指数分布する場合を仮定して, ヘリカル コイル の集合構造を決め見掛けの系の外径とこれら分布との関 係を数学的傽計算した.

本報はての仮定の妥当性を確認するため, 実際の系に ついてまず巻縮纎維の位相差の計測方法を導き，ついで 巻縮性と位相差の関係を実験的に調べ第 1 報の理諭の妥 当性の確認を行なう.

\section{2. 理論一巻縮波形の相互相関関数計測によ る位相差測定法}

以上述べたヘリカルコイルのモデルにほぼ近いスパ イラル状のクリンプを有する瀻維で作った，甘撚双系の 紡績系について観察を行なった. 第 1 報の写真に示した ように, 単繊維の長さ当たりの巻縮数が多い系はクリン プ相互の位置が比較的ランダムになっており, 巻緶数の 少ない糸は単緘維の巻縮波形の位相が比較的よくそろっ ている傾向がある.しかしてれらの系を形成する単繊維 巻縮について正確に相互の位相関係を吟味するために は，たとえば系を透明なプラスチックスで包埋固定して 系の断面より追跡していく方法があるがての場合のよう に $\theta$ の分布という統計的処理を必要とする実験には測定 個数が多くなり労力と繁雑さの点から非常に困難な仕事 になる。

そこで相互相関法を提案したい。いま仮定としてつぎ の二つを扔く。

〔仮定 1〕一つの系断面を構成する繊維のうち相互に 接触しあう繊維の位相差之任意の 2 本の繊維間の位相差 とはこれぞれの集合平均在とることによって一致する。

〔仮定 2〕系中で立体的に配置しているクリンプ瀻維 が実際の系中の位置から，投影像を得るための移動によ り，ヘリカル軸がある角度をあって回転されることは不 可避であるが，この角度はランダムで偏りはないものと する.

半径 $a$ のヘリカルコイルを考え, これに対して位相
差 $\theta$ のあう一つのヘリカル コイルは第 1 図に示すよう に中心軸のまわりに $\theta$ 回転させて得られる。

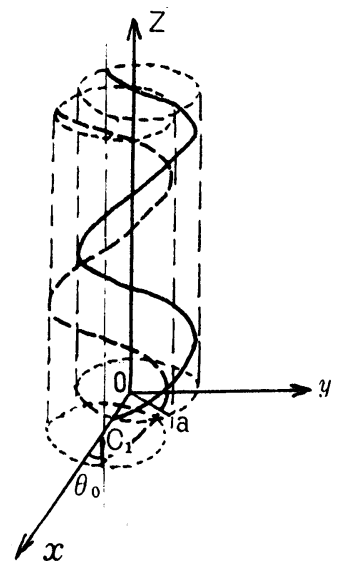

(第 1 図)オーバーラップする ヘリカルコイル モデル

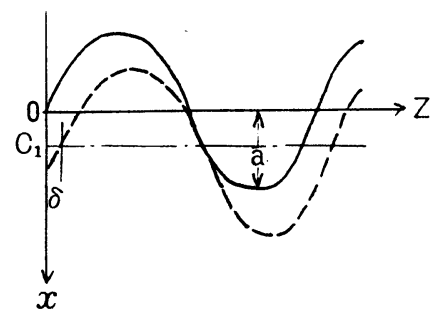

（第 2 図） $x-\boldsymbol{z}$ 平面に投影した ヘリカルコイルモデル

乙れを $x-z$ 平面传投影した図が第 2 図で $\theta=\delta$ であ る. $\delta$ の計測によって位相差 $\theta$ が求められる. 系中の個 々の巻縮緘維をへリカルコイルとみなしてその位相差 を求めるために上記〔仮定 1〕〔〔仮定 2〕により投影図を 得た。すなわち投影図においてクリンプの長さ方向の位 置をそろえるため系の一定の長さを染め分けてマーク付 けし，マークのついた任意の繊維を平面図に投影した。 投影図より各瀻維の卷綰波形の相互相関関数を求めた.

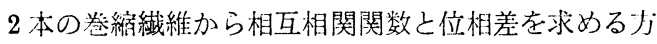
法について述べる. 平面四に投影された巻縮の形状を模 式的に第 3,4 図涂す.

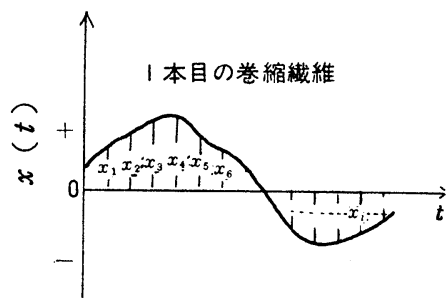

（第 3 四）1 本目の巻縮緎維の模式図 


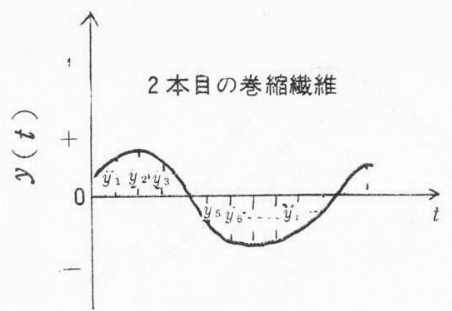

（第 4 図） 2 本目の巻縮織維の模式図

図はクリンプの中心軸を $x=0$ あるいは $y=0$ とお き, 問題とする巻縮ピッチの 10 等分程度の間隔で（本 研究では $\Delta t=0.16 \mathrm{~mm}), x(t), y(t)$ を求め, その值が $x_{1}, x_{2}, x_{3}, \cdots \cdots, x_{i}, \cdots \cdots x_{n}$ と $y_{1}, y_{2}, y_{3}, \cdots \cdots$. $y_{i}, \cdots \cdots y_{n}$ とになるととを示している。

1 本目上 2 本目の巻縮の波の相互相関は

$$
R_{0}=\frac{1}{N} \sum_{i=1}^{N} x_{i} y_{i}
$$

2 本目を $k \Delta t(k=1,2,3 \cdots \cdots)$ だけずらした ときは

$$
R_{k}=\frac{1}{N-k} \sum_{i=1}^{N-k} x_{i} \cdot y_{i+k}
$$

$R_{k}$ を縦軸にとり，横軸に $k \Delta t(\equiv \tau)$ をとる．乙うし て得られた関数 $R(\tau)$ は相互相関関数と呼ばれる。 $R$

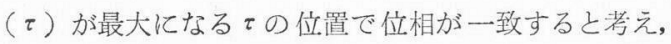
この位置を平均巻縮ピッチより位相差に換算するととに より位相差の計測を行なった。

系中での繊維の接触は1本だけでなく，多数本にわた っていると思われるが, 第 1 報の理論計算に用いた本数 が 3 本 1 組として構成纎維本数全体の統計姏理を行なっ た. 位相差の計測も互いに接触しあう最小本数として 3 本を 1 組として行なった。

任意に取出した 3 本 1 組の繊維について 1 本目の巻縮 を基準に二つの位相差 $\theta_{01}, \theta_{02}$ が求まる.このような 各 3 本ずつの組合わせについて系構成本数すべてを取出 し位相差を求める.さらに基準繊維として任意の 1 本を 決め, 各 3 本 1 組の 1 本目が基準繊維との位相差をどれ だけ有するかを求めおのおの基準織維に対しどれだけの
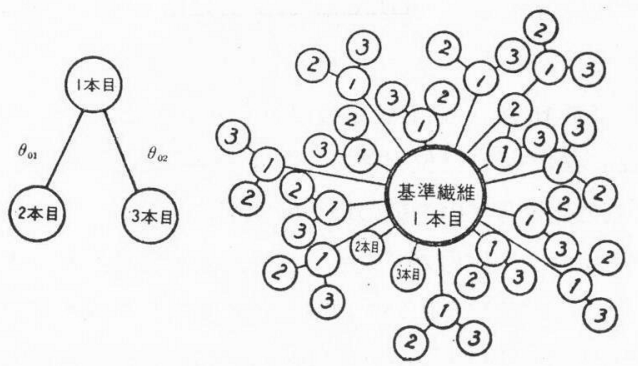

（第 5 図）位相差分布を求めるための組立図
位相差になるか換算し，位相差の行布状態が求められる。

\section{3. 実 験 方法}

実験に用いた試料は第 1 報と同じ試料（ポリエステル 繊維) でスパイラルクリンプを有する瀻維の甘撚奴糸 の紡績系を用いた。

糸のマーク付けは染色時系端を鉄片にはさみ押压して 染め分けた。

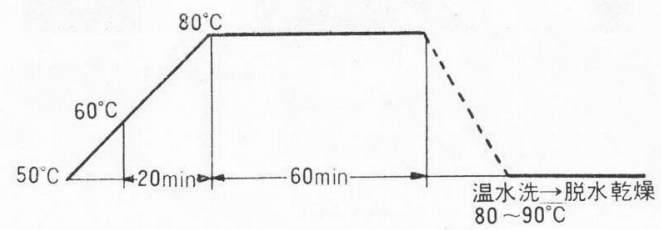

染料: Eastman Polyester Blue GLF 分散剂：モノゲン 浴比: $1: 50$ 染料濃度： $4 \%$ owf

（第 6 図）染色条件

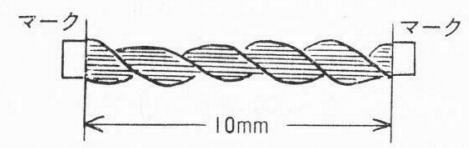

（第 7 図）マーク付け後供試試料模式図

糸の構成繊維は 94〜100本であったが紡績系のため試 料の両端の長さに達しない緎維もあるので測定に応じえ た繊維本数は63本であった。系より任意に取出した単繊 維を紙の密枠にマークが厳密にそろうようにしてはり つけ，撚りの効果をなくするために $10 \%$ 伸ばしてスラ イドグラス上に固定した。第 8,9 図はマーク付けした 糸およびスライド グラス上に固定した単繊維のおのお の側面写真を示す.

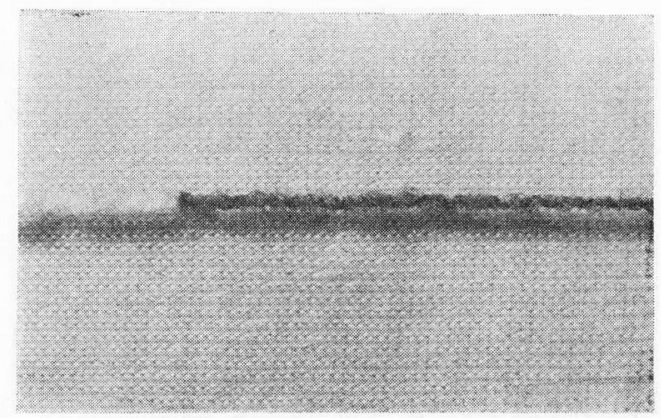

（第 8 図）染色によりマーク付けされた系

スライドグラス上で押しつぶされないように固定し てあるクリンプを約 30 倍（31.5 倍）に投映機で拡大し クリンプの波を描写してれより, 第 3 図や第 4 図で示し た巻縮の波形として, 波の相互相関関数を求めた.

ここで

$\Delta t=0.16 \mathrm{~mm}(\equiv \tau)$ 


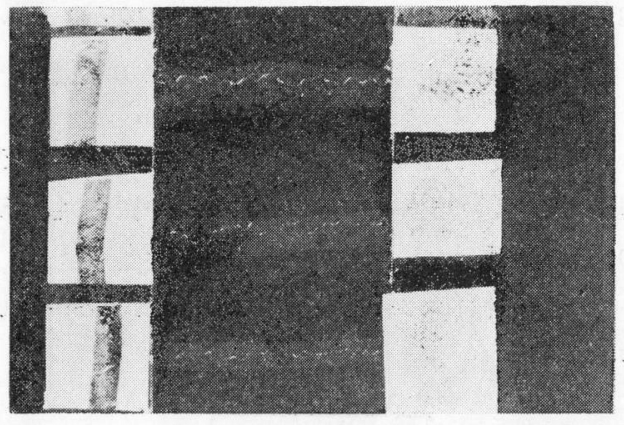

（第 9 図）スライドグラス上に固定された単織維

$$
\begin{aligned}
R_{k} & =\frac{1}{N-k} \sum_{i=1}^{N-k} x_{i} \cdot y_{i+k} \\
N & =50 \text { (実測長さ } 8.0 \mathrm{~mm} \text { ) } \\
k & =0 \sim 10
\end{aligned}
$$

先に詳述したように $R(\tau)$ を縦軸に横軸には $\tau$ をと って, $R(\tau)$ が最大になる $\tau$ の位置で位相が一致した之 みなして,その位相差を 1 ピッチ $360^{\circ}$ として換算した。 実験に用いた試料では

高巻縮 (巻縮数 22 山 $/ 25 \mathrm{~mm}$ ) : 1 ピッチ $360^{\circ}=\frac{25}{22}$ $=1.138 \mathrm{~mm}$

$$
1 \text { ピッチ } 360^{\circ}=\frac{1.138}{0.16}=7.1 \tau
$$

中巻縮 (巻縮数 13.9 山 $/ 25 \mathrm{~mm}$ ) : 1 ピッチ $360^{\circ}=\frac{25}{13.9}$ $=1.80 \mathrm{~mm}$

$$
1 \text { ピッチ } 360^{\circ}=\frac{1.80}{0.16}=11.3 \tau
$$

によって換算した.

\section{4. 結果および考察}

スライドにて拡大描写したクリンプ波形の一例を高巻 縮, 中巻縮について一組ずつ第 10 図, 第 11 図に示す. この図の波について求めた $R(\tau)-\tau の$ 相互相関関数

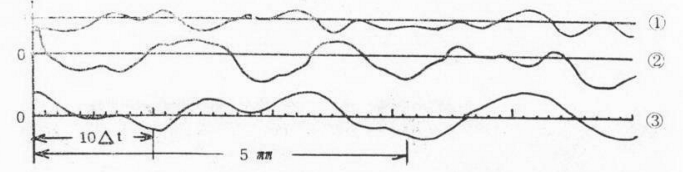

（第10図）中巻縮の投影拡大図の一例

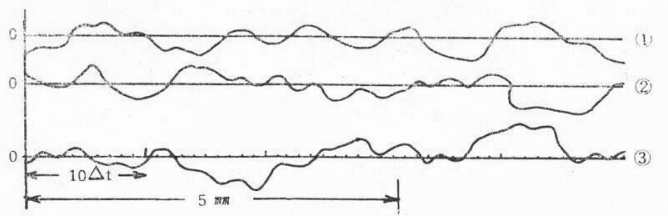

（第 11 図）高卷維の投影抎大図の一例

のグラフをおの㧍の第 12 図と第 13 図に示す.

第 12,13 眓の相互相関関数 $R(\tau)$ は $\tau$ の増加とともに 変化し最大值を有する曲線となり, 相互相関関数の計測

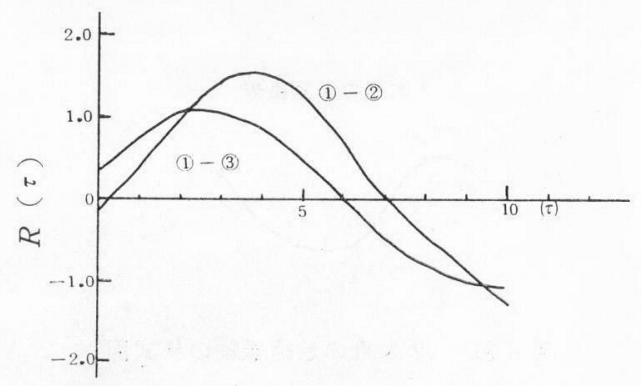

（第 12 図）中巻縮 $R(\tau)-\tau$ の一例

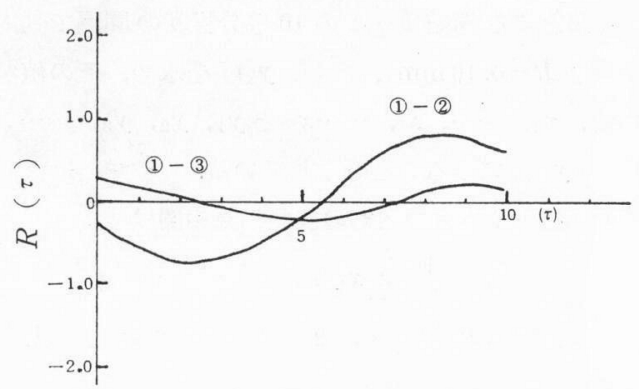

（第 13 図）高巻縮 $R(\tau)-\tau$ の一例

方法の項で予想したような結果が得られることな示して いる. $R(\tau)$ が最大になるての位置で位相が一致したと 考えこの位置を平均巻縮ピッチより位相差に換算した。 糸構成繊維すべてについて位相差を求め位相差の分布 状態を求めると第 14,15 図のようになる.

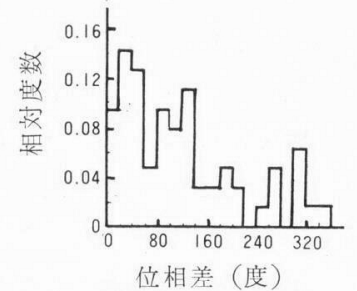

（第 14 図）中巻縮系の位相差の相対度数分布

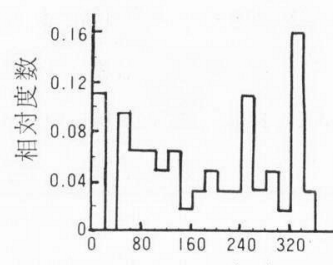

位相差（度）

（第15 図）高巻縮系の位相差の相対度数分布 高巻縮の場合は位相差の分布はランダム分布に近い. これに比較して中巻縮の場合は位相差の小さい側に分布 密度が高く，位相差の大きい側では低くなる。本研究第 1 報の指数乱数を用いて理論計算に使用した位相差の分 布状態を第 16 図に示し一様乱数を用いて理論計算に使 用した位相差の分布状態第 17 図に示す. 


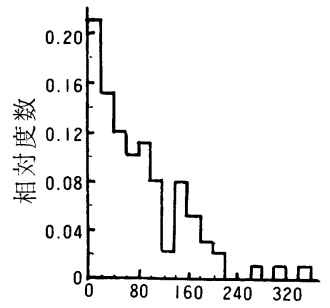

位相差（度）

（第 16 図）指数乱数 $1 / \lambda=0.25$ を計算に 用いた場合の位相差分布

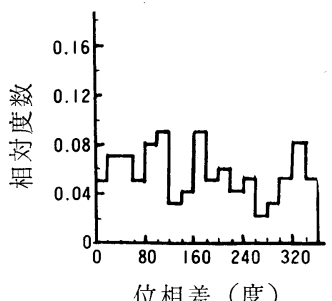

（第 17 図）一様乱数を計算に用いた 場合の位相差分布

中巻縮の場合は指数分布の位相差に近く, 高卷縮の場 合には $\theta=0 \sim 360^{\circ}$ の間の一様な分布の位相差に近い. これは糸の見掛け太さから検証した第 1 報の結果と合致 かる.

巻縮の位相のずれが系の構造を決定する非常に重要 なファクターであり, 系の集合構造の重要因子として取 上げたヘリカルコイルの集合構造理論の妥当性が確認 される.

なお第 12,13 図のグラフ太比較すると中巻縮の方が 高巻縮より相互相関関数の最大值が大きい. そこで全測 定結果について $|R(\tau)| \max$ の值を調べると第 18,19 図のようになり, 中巻縮は $R(\tau)$ の最大值は大きいが, 高巻縮の $R(\tau)$ の最大值は小さい值に集中している.

本研究は巻縮ピッチが一定であるという仮定で進めて いるが, $R(\tau)$ のピークが小さいというととは本研究

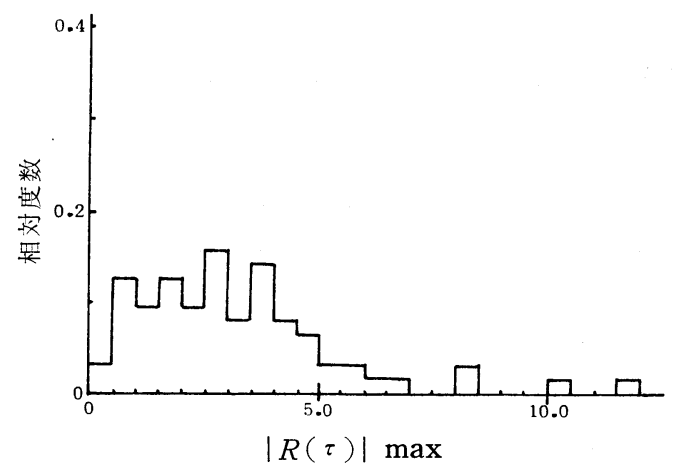

（第 18 図）中巻縮における $|R(\tau)|$ $\max$ の相対度数分布

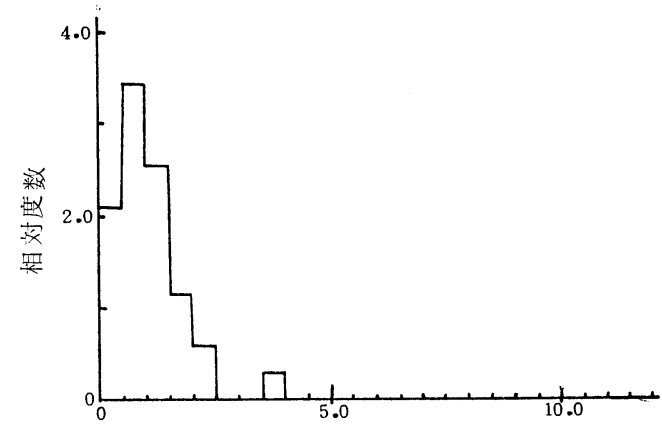

$|R(\tau)| \max$

(第 19 図) 高巻縮における $|R(\tau)|$

$\max$ の相対度数分布

モデル構造からの ずれが生じているととを示している. しかし本研究で行なった統計的処理法はこうした場合あ 含めて位相差の分布の推定に適した方法であることは相 互相関関数の性格から想像されるところである.しかし 巻縮数が多くなると上述の仮定からのずれの度合が大 きく，乙の効果がバルキー化に寄与することが考えられ 今後の検討すべき問題になっている.

\section{5. 結語}

系の集合構造を決める巻縮の位相ずれの計測方法を提 示し, 実際の巻縮系のもつ位相差を計測し，巻縮性と位 相差との関係を明らかにした。

1) 系内の巻縮の位相ずれは巻縮波形の相互.相関関数 で把握する方法を提出した。

2) 2 本の繊維閒の巻縮の位相のずれは卷縮波形の 相互相関関数が最大の值太示すときの觕度より計算で き, 糸のバルキ一性から逆算して推定される位相差の分 布とほぼ一致した。これは第 1 報の糸の集合構造理論に 妥当性のあるととな示した。

3）巻縮数の少ない場合は巻縮䋐維間の波形の位相ず れが少ないが巻縮数の多いものについては位相ずれが ランダムになって $\theta=0 \sim 360^{\circ}$ の間をほぼ一様に分布 する.

終わりに本研究に対して種々有益なで討論をいただい た京都大学工学部高分子化学教室内䋐維集合体力学研究 会の方々に深く感謝する.

なお本報文の一部は昭和 46 年 6 月本学会年次大会に おいて発表した。

\section{文献}

1) 山口，川端；本誌投稿中

2) 野呂田, 川端, 河合; 瀻機誌論文集, 22, No. $7 / 8$ $\mathrm{T}-168$ (1769) 